(3) It reaches even the highest centres, but simply touches them and does not enter them.

(4) It enters them, but fails to bring about that physical change in them that is the invariable concomitant of every conscious state.

The first of these explanations appears to me the least tenable of all. The last explanation, on the other hand, seems to be relatively the most probable. Indeed, on purely psychological grounds I am inclined to accept it as the final solution, but I must wait and seek an explanation on strictly physiological lines.

Ghasiari-Mandi, Lucknow, India.

ABDul Majid.

IN reply to your inquiry for information upon the question raised by Mr. Majid I beg to say that the view of the matter which is, I think, pretty generally accepted and which I have adopted and attempted to develop in several publications (more especially in a series of papers in Mind, vol. xv., "Physiological Factors of the Attention Process"), is that the central nervous system consists of series of sensor-motor arcs superimposed on one another to form strata of successively higher function from below upwards; that the synapses or cell-junctions of the higher level arcs offer higher resistance in the resting state than those of arcs of lower level; that the walking state is essentially one in which the generally diffused excitement of the whole system reduces these resistances of the higher levels to such degree that excitations from lower levels can penetrate them, such penetration being impossible in the quiescent state owing to the high degrees of resistance presented by the synapses of these higher levels.

Anxesthetic drugs (as I first suggested in Mind in I 898 ) seem to abolish consciousness through increasing the resistances of the synapses; and fatigue-products probably act on them in a similar manner, thut's cooperating with diminution of external stimuli to the sense-organs in predisposing to or inducing normal sleep. I know of no evidence that points towards Mr. Abdu' Majid's fourth type of explanation. His letter raises an interesting question, which is by no means settled, although the type of explanation I suggest is, I think, more or less tentatively accepted by a good :many physiologists; and it would be of interest to elicit some expressions of opinion.

Oxford, August 7 .

\section{W. McDougall.}

\section{FOSSIL MAN.1}

IN the summer of I9o8 the Abbés A. and $J$. Bouysonnie and L. Bardon, already distinguished for their researches into the Palæolithic industries in France, made an important discovery. At La Chapelle-aux-Saints, a little south of Brive, in the Department of Corrèze, they found buried in a grave of Mousterian age a human skeleton of Neandertal type, with the head more completely preserved than in any previously known example of its kind. An inquest was held on the spot by some of the best-known "prehistorians" in France, who unanimously confirmed the observations of the discoverers. The skeleton, which Messrs. Bouysonnie and Bardon have generously presented to the National Museum of Palæontology in Paris, was entrusted by a fortunate choice to the director, Prof. Boule, and the result of his 1 "L'Homme Fossile de la Chapelle-aux-Sainte." By Prof. M. Boule. Pp. $275+x v i$ plates. (Paris: Masson et Cie., 1913.) Price 50 francs. No. 2287 , VOI. 9I] investigations is the beautiful monograph before us.

The first chapter is devoted to a history of the discovery. The skeleton was found lying in a hollow of the rocky limestone floor of the cave, and was covered by a magna of broken bones, worked flints, and yellow cave-earth, over which followed first a layer of clay and then of loose soil containing pebbles. Among the animals represented by the bones are the woolly rhinoceros, reindeer, bison, hyæna, marmot, and horse--a characteristic Pleistocene fauna. The implements are for the most part Mousterian points and racloirs; there are a few bouchers of Acheulean type, as well as some grattoirs which seem to presage the Aurignacian; but the assemblage as a whole is typical Mousterian.

The skeleton was orientated east and west, the head to the west. Above the head were the bones of a bison's foot (a metatarsal and some phalanges) still in connection-a proof that the deposits had not been disturbed, and suggestive of much else besides.

The skull (Fig. I), of which a masterly analysis is given, is unusually perfect, and especially in

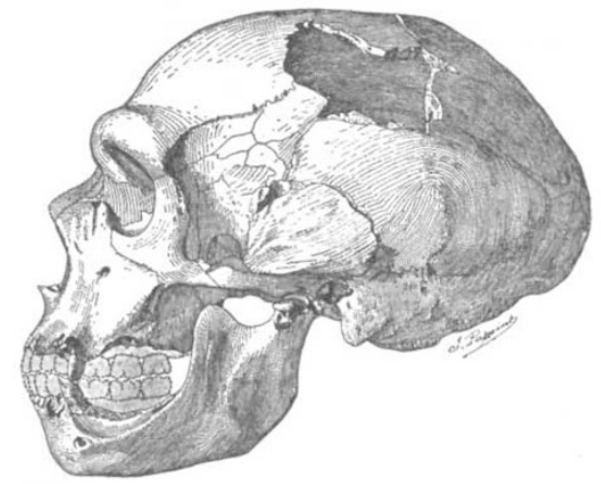

FIG. x.-Skull of the man of La Chapelle-aux-Saints, with the nasal bones and the dentition restored $\left(\times \frac{1}{1}\right)$

those parts which are absent from the Gibraltar skull, so that it is possible to determine the position of such important points of reference as the basion, opisthion, and bregma. The base is unfortunately incomplete, and this is the more to be regretted as the base of the Gibraltar skull, which in some respects is better preserved, presents some peculiar features not yet perhaps fully explained. In general there is a strong resemblance between these two skulls, the most marked difference, apart from size, lying in the extreme prognathism of the skull from La Chapelle-aux-Saints. Prof. Boule suggests that the orthognathism of the Gibraltar skull may be due to distortion conse quent on pressure, but in the absence of collateral evidence we should be more inclined to regard it as an individual variation.

The most important characters of the skull are as follows : it is very large, especially for a man whose stature did not exceed $x^{\circ} 6$ metres, and its capacity, measured directly by Flower's method is I620 c.c. The capacity of the Neandertal skul: 
is estimated at I 408 c.c., of La Quina at 1367 c.c., and of Gibraltar at 1296 c.c.

It is long, almost mesocephalic, and very flat: the frontal torus is enormous, the forehead low and retreating; there is a marked occipital torus, and the foramen magnum is situated far backwards; the squamosal is small, the mastoid process reduced, the tympanic slightly compressed, and there is a rudimentary post-glenoid apophysis. The palate is very large. The face has a remarkably brutal appearance, due partly to the retreating forehead and the frontal torus, the great round orbits, and very broad nose, but above all to the massive maxilla, which is without a canine fossa, and projects forwards, continuing the direction of the jugal, to form a sort of snout. The lower jaw is distinguished by the great thick-

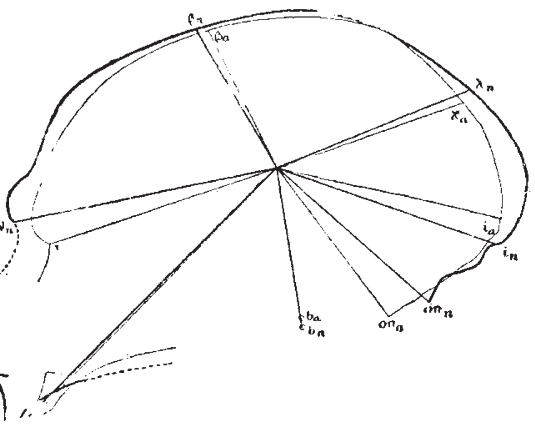

FIG. 2.-Profile of the skull of the man of La Chapelle-aux-Saints (thick line) compared with that of a low Australian aborigine (thin line). (The inions should be interchanged.)

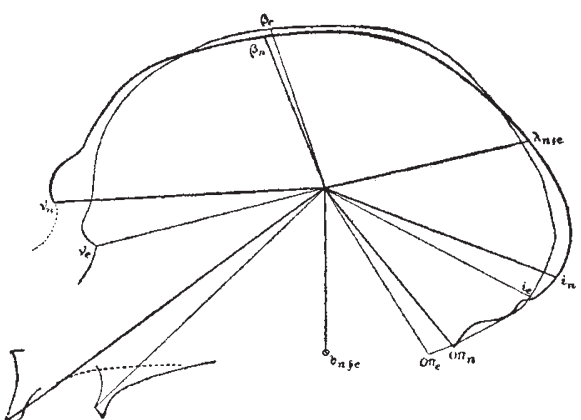

Fig. 3.-Profile of the skull of the man of La Chapelle-aux-Saints (thick line) compared with that of an average European (thin line).

ness of its body, the breadth of the ascending ramus, the obliquity of the symphysis, and the complete absence of a chin. The dentition is megalodont.

As the author justly remarks, it is not so much the occurrence of one or other of these characters which distinguishes the head of Neandertal man (many of them may be found scattered up and down among the members of some existing races); it is rather the association of all of them in one and the same skull, and, so far as we know, in all the skulls of one and the same race.

Very complete measurements are given, but exception might fairly be taken to the use of the glabella-inion line as a base; this is not without value when the Neandertal skulls are compared NO. 2287 , VOL. $9 I]$ inter se, but it becomes misleading when the comparison is extended to the skulls of existing races. A better method is to superpose sagittal sections on a line drawn from the basion to the centre of form of its cranial area, as in the accompanying illustrations (Figs. 2 and 3 ).

It was found possible to obtain an internal cast of the skull, and thus to throw some light on the form of the brain, which, notwithstanding its magnitude, presents several simian features. It would be interesting to know what psychological significance may attach to these; Prof. Boule's

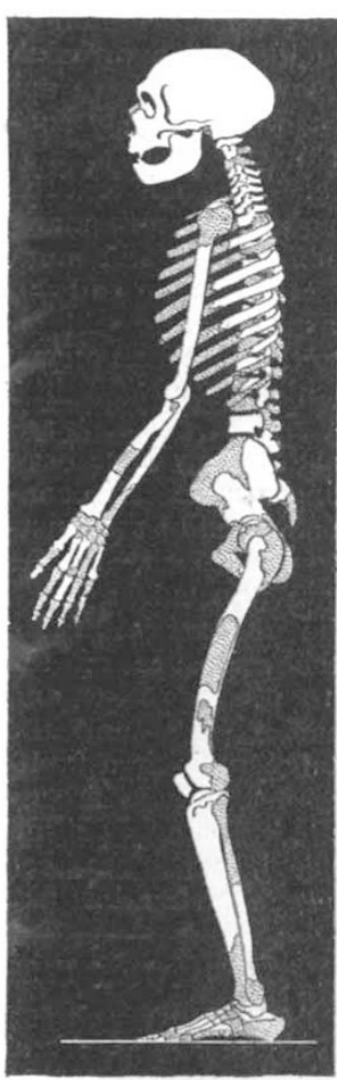

FIG. 4.-The skeleton of the man of La Chapelle-aux-Saints restored $(\times 15)$

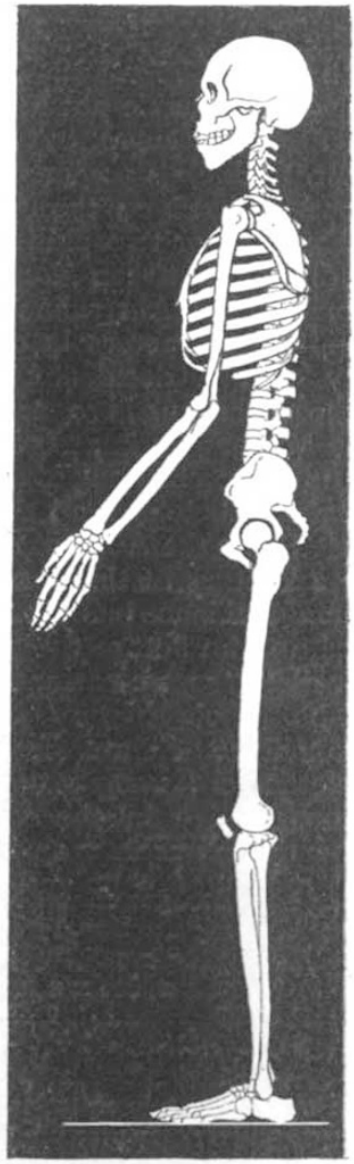

FIG. 5.-The skeleton of an Australian aborigine for compar son with Fig. $3\left(\times_{15}\right)$ comment is that a small watch may be a better timekeeper than a big clock.

A minute description of the other bones of the skeleton brings to light a number of interesting peculiarities, as in the form of the scapula and the clavicle, the characters of the cervical vertebræ, and others which are summarised in a useful table (pp. 222-6).

In discussing the stature it is pointed out that Manouvrier's rules are founded exclusively on a study of existing white races, and that other factors have to be taken into account when we proceed to extinct races like the Neandertal. Prof. Boule is thus led to assign a stature of from 
I'58-I'59 to the man of La Chapelle-aux-Saints, or even perhaps $10 \mathrm{~mm}$. less. The attitude is regarded as having been less habitually erect than in recent races.

The numerous and important differences which we encounter in all patts of the skeleton are sufficient to distinguish Neandertal man from all existing races; he differs more from them than they from one another, and is therefore to be regarded as a distinct species, which, according to the recognised rules of nomenclature, should be named Homo neandertalensis.

All anthropologists will welcome the very interesting chapters on fossil Pleistocene man and the evolution of mankind which conclude the work. They are valuable not merely as a compendium of existing knowledge, but above all as an expression of Prof. Boule's personal opinions. We have not space to dwell on these, but we may briefly enumerate one or two points. No very close affinity is admitted between Homo neandertalensis and the aborigines of Australia; though they share many primitive characters in common, yet in still more they offer a decided contrast (Figs. 4 and 5). Pithecanthropus is regarded as a gigantic gibbon. The Mauer jaw is assigned to the Chellean stage. Some resemblance is recognised between the Grimaldi skeleton and the Bushmen, and it is admitted that the Aurignacian artists may have been the ancestors of this interesting people. No convincing evidence has yet been adduced of the existence of man before the Pleistocene epoch, and the so-called "rostro-carinates" are rejected.

The whole history of the discovery at La Chapelle-aux-Saints, from the exposure of the skeleton in its tomb down to its lodgment and reconstruction in the museum at Paris and the appearance of this monumental memoir, is a faultless record of skill and foresight. There are no lost opportunities to be regretted, and every significant fact that the material could yield has been elicited and set before us by a master hand.

\section{THE AUSTRALIAN MEETING OF THE BRITISH ASSOCIATION IN I9I4.}

Projected Tours before And after the Meeting. BESIDES numerous excursions, in some cases over long distances, which are being arranged in connection with the meetings in the different capital cities of Australia next year, two more extended tours are projected with the object of giving selected members of the main party an opportunity to see portions of the continent which will otherwise not be touched. The first of these will be in Western Australia, and will be open to a limited advance party composed mainly of geologists, zoologists, anthropologists, and botanists.

The work of the party will lie in various directions from Perth. Geologists will be taken east to the goldfields, and also north to the Irwin River district. The geological relations of the latter (permo-carboniferous glacial beds with good exposures, and with excellent opportunity for collecting specimens) are more readily grasped on a short visit than are those of the goldfields. In NO. 2287 , VOL. 9r] addition an excursion will be arranged to Yallingup (south from Perth), and here there will be opportunity for botanists and zoologists to collect. For the latter, also, a marine excursion with dredging will be arranged at Bunbury on the return journey. A shorter trip by motor from Perth to Mundaring Weir will interest the same members, the zoologists visiting the region where Peripatus occurs. Marine dredging excursions in Swan River (for Ascidians), and by Rottnest Island, will also be arranged.

As regards the time that is required for a satisfactory working of the programme, a week is a minimum, and will mean much crowding and hurry. The Government of Western Australia and the committee in charge of matters connected with the visit would welcome a stay of a fortnight, and are prepared to grant railway facilities and find hospitality for that time. The number in the party must be limited, and membership restricted to people who are keenly interested in the work proposed. Twenty-five to thirty would be a convenient number, which might, perhaps, be extended to thirty-five, but must not exceed this.

The second tour would begin after the last meeting of the association in Brisbane, and the proposed itinerary is the following:-Brisbane viâ Rockhampton to Longreach by rail; coach to Winton; rail to Hughenden and Cloncurry; motor to Croydon and rail to Normanton. The party would then be taken to the mouth of the Norman river, and be met by the steamer belonging to the Administration of the Northern Territory (Dr. J. A. Gilruth, Administrator), and conveyed across the Gulf of Carpentaria, and about one hundred miles up the Roper river. They would proceed through the Territory by motor-car (there are no roads) to Pine Creek, and thence by rail to Darwin, where the steamer to England viâ Java, Singapore, and Colombo would be met.

A very considerable portion of Australia would be covered, and fine opportunities offered for the study of botany, geology, agriculture, \&c., and, what is of great importance to Australia at the present time, the conditions of white settlement in the tropics. Obviously the party must be small, and it is suggested that it should include a botanist, a geologist, a zoologist, and a physiologist, or persons connected with mining, agriculture, and the development of Empire. Four would be a suitable number, or at the most five. Representative men only would be acceptable, for the trip will be costly; but if a party of sufficient standing and enthusiasm be prepared to undertake it, the Hon. D. F. Denham, Premier of Queensland, has promised, on behalf of his Government, to bear the expenses of the Queensland section, and the Administration of the Northern Territory will be responsible for the later section. A rough estimate of the time that might be spent on the whole trip is one month, but this would need to be adjusted in accordance with the time-table of the boats from Darwin to England. 